\title{
Different variants of equine hemangiosarcomas
}

\author{
Dana Teschner', Robert Ralf Schmitz', Ann-Kristin Barton', Robert Klopfleisch² and Heidrun Gehlen ${ }^{7}$ \\ Klinik für Pferde, Allgemeine Chirurgie und Radiologie, Freie Universität Berlin, Germany \\ 2 Institut für Tierpathologie, Freie Universität Berlin, Germany
}

\begin{abstract}
Summary: Hemangiosarcomas in horses are rare. Four cases of different localizations of hemangiosarcomas in horses are described. A 21 -year-old draft horse gelding was presented at the Equine Clinic with signs of colic. He showed no abnormalities at the clinical examination and the laboratory. Because of a pain attack, his neck was examined radiologically and a fracture of C3 was revealed. To the best of our knowledge, this is the first report about a pathological fracture of a cervical vertebra due to a primary hemangiosarcoma in horses. The second and third cases showed a hemangiosarcoma in the abdominal and the thoracic cavity, respectively. In the fourth case, a hemangiosarcoma was found in the musculature of the chest wall. They showed typical signs and laboratory alterations of this neoplasm. Cytological examination revealed the suspicion of hemangiosarcoma in three of these cases.
\end{abstract}

Keywords: horse / hemangiosarcoma / pathological cervical vertebral fracture / oncology

Citation: Teschner D., Schmitz R. R., Barton A.-K., Klopfleisch R., Gehlen H. (2014) Different variants of equine hemangiosarcomas. Pferdeheilkunde 30, 551-556

Correspondence: Dr. Dana Teschner, Freie Universität Berlin, Klinik für Pferde, Oertzenweg 19b, 14163 Berlin, E-Mail: dana.teschner@ vetmed.fu-berlin.de

\section{Introduction}

Vascular neoplasms are rare in horses. Hemangiosarcomas are malignant tumors originating from the vascular endothelium and show a close association to the vascular system (Tyler et al. 2002). Local occurrence at the eye (Gearhart et al. 2007), in the skin and submucosa, in the lungs and pleu$\mathrm{ra}$, in the skeletal muscles, and in the spleen (Southwood et al. 2000) have been described. Local invasion into bone tissue (Johns et al. 2005), paranasal sinuses (Cissel et al. 2012) and the oral cavity (Dunkel et al. 2004), as well as the disseminated form have been reported in horses. Hemangiosarcomas also originate primarily from bone tissue. Vertebrae and flat bones of the cranium or pelvis are preferred locations (Kiupel et al. 2000). These neoplasms show a rapid, infiltrative growth and metastases in lungs, spleen, kidney, liver, and brain. Common clinical signs include tachycardia, tachypnea, and pectoral, ventral midline and distal limb edema (Southwood et al. 2000). Pleural and abdominal effusions and sanguineous transudate in the abdominal or thoracic cavity are additional common findings. Cytological examination of these aspirates possibly allows an intra-vitam diagnosis of neoplasia (Recknagel et al. 2012, Schmitz and Grabner 2008). Common laboratory abnormalities in these patients are anemia, neutrophilic leukocytosis and thrombocytopenia (Southwood et al. 2000) and can substantiate suspicion of neoplasia. Furthermore, the increased enzyme activities of lactate dehydrogenase $(\mathrm{LDH})$, aspartate aminotransferase (AST) and creatine kinase (CK) can be considered indicative of disease.

\section{Case series}

Case 1

A 21 -year-old draft horse gelding was referred to the Equine Clinic presenting mild signs of colic (lying down, teeth-grinding and decreased appetite). At arrival, the gelding showed no signs of colic and physical examination did not reveal any abnormalities. Transrectal palpation and passage of the nasogastric tube remained unremarkable. The laboratory parameters were within the reference values. The ultrasonographic examination of the abdominal cavity and cytological examination of the aspirate revealed no abnormalities. The gelding showed a spontaneous pain attack while being hand walked. The neurological examination revealed a reduced and painful cervical mobility to the left and right side as well as downwards. No ataxia or lameness were present. Laterolateral as well as oblique radiographic images of the cervical vertebrae were acquired using a computed radiography system (AGFA DX-G; AGFA Healthcare, Greenville, SC). The film focus distance was $100 \mathrm{~cm}$, exposure value was 74 kilo voltage and the exposure time was 0.12 seconds. The radiographic examination revealed a complete fracture of the caudoventral aspect of the third cervical vertebral body. The fragment was markedly ventrally dislocated. Additionally, the vertebral body of C3 showed a mottled opacity (Fig. 1 and 2). Cervical spine trauma had not been observed, but could not be ruled out either. Due to the guarded prognosis, the gelding was euthanized in agreement with the owners. Necropsy revealed a pathological fracture of the caudoventral aspect of C3 due to a hemangiosarcoma (Fig. 3, 4 and 5) with an additional infiltration of the adjacent ventral cervical muscles. Maceration and HE stain, according to standard protocols (Klopfleisch et al., 2010), confirmed the diagnosis of a hemangiosarcoma without metastatic spread to other organs.

\section{Case 2}

A 28-year-old standardbred mare was presented at the Equine Clinic with a history of weight loss and chronic diarrhea of a few weeks duration. Additionally, recurrent epistaxis and anemia were reported by the referring veterinarian. Depression, tachycardia of $60 \mathrm{bpm}$ (reference range $28-40 \mathrm{bpm}$ ), 
tachypnea of $20 \mathrm{bpm}$ (reference range $8-16 \mathrm{bpm}$ ), and fever $\left(38.6^{\circ} \mathrm{C}\right.$; reference range $\left.37-38^{\circ} \mathrm{C}\right)$ were noted in the clinical examination. The laboratory findings included a neutrophilic leukocytosis of $15.3 \times 10^{9} / \mathrm{l}$ (reference range $5-10 \times 10^{9} / \mathrm{I}$ ), marked anemia with a PCV of $16 \%$ (reference range $25-35 \%$ ) and a severe thrombocytopenia of $16 \times 10^{9} / 1$ (reference range $\left.90-250 \times 10^{9} / \mathrm{l}\right)$. The enzyme activity of lactate dehydrogenase $(1007 \mathrm{U} / \mathrm{I}$, reference range $<250 \mathrm{U} / \mathrm{I})$, as well as the plasma ionized calcium level $(3.08 \mathrm{mmol} / \mathrm{l}$; reference range $1.5-1.8 \mathrm{mmol} / \mathrm{l})$ were above the reference values.

Endoscopic examination revealed a slight blood rill out of the left aditus nasomaxillaris. A nodular surface of the spleen could be palpated transrectally. The ultrasonographic examination showed multiple hypoechogenic spots in both kidneys and the spleen. The cytological examination of the abdominal fluid revealed prominent cell transformation with spindloid cells, basophilic and vacuolated cytoplasm, and harsh chromatin patterns of the nucleoli. A hemangiosarcoma was suspected (Fig. 6). The mare was euthanized in agreement with the owners. At necropsy, a tumor of $30 \mathrm{~cm}$ diameter was found at the mesentery, including the left kidney, left adrenal gland, spleen, and the mesocolon of the left ascending

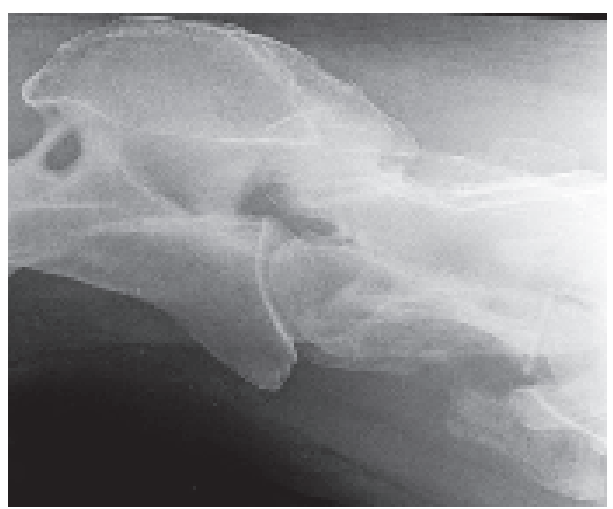

Fig. 1 Latero-lateral radiograph of the cervical vertebrae (C2C3): fracture of the ventrocaudal aspect of the third vertebral body with ventral dislocation of the fragment, and mottled opacity of the ventrocaudal aspect of the vertebral body

Latero-laterale Röntgenaufnahme des 2. und 3. Halswirbels: Fraktur des ventrocaudalen Anteils des 3. Halswirbels mit ventraler Verlagerung des Fragmentes, auffällig ist auch die unrege/mäßige Wirbelstruktur

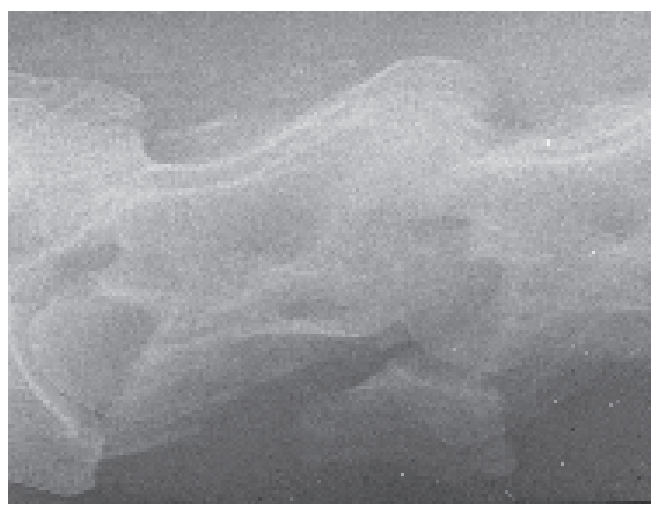

Fig.2 Latero-lateral radiograph of the cervical vertebrae (C2C3): fracture of the ventrocaudal aspect of the third vertebral body with ventral dislocation of the fragment

Latero-laterale Röntgenaufnahme der cranialen Halswirbel (C2-C3): Fraktur des ventrocaudalen Anteils des 3. Halswirbels mit ventraler Verlagerung des Fragmentes colon. Multiple encapsulated nodes of $0.5 \mathrm{~cm}$ in diameter were found in the liver, both kidneys, both adrenal glands, and the lung, and were diagnosed histologically as a severe metastasizing hemangiosarcoma.

\section{Case 3}

A 20-year-old warmblood mare was presented at the Equine Clinic having shown tachycardia and tachypnea for two days. The mare was severely depressed, had a tachycardia of $60 \mathrm{bpm}$ and a tachypnea of $28 \mathrm{bpm}$ (reference ranges above). The laboratory findings included hypoproteinemia of $4.4 \mathrm{~g} / \mathrm{dl}$ (reference range $6-8 \mathrm{~g} / \mathrm{dl}$ ), a PCV of $31 \%$, thrombocytopenia of $26 \times 10^{9} / \mathrm{l}$, and hyperglycemia of $7.8 \mathrm{mmol} / \mathrm{I}$ (reference range $2.8-5 \mathrm{mmol} / \mathrm{l})$. Arterial blood gas analysis revealed a severely decreased partial oxygen pressure of $58.5 \mathrm{mmHg}$ (reference range $95-10^{5} \mathrm{mmHg}$ ). Auscultation of the thorax afforded dull ventral lung sounds. Severe thoracic effusion was found radiographically and by ultrasonography. The spleen revealed some hypoechogenic spots on ultrasonography of the abdominal cavity. Thoracocentesis yielded the aspiration of a transudate, including $2.2 \times 10^{9} / \mathrm{l}$ leukocytes, a PCV of $6.8 \%$ and a total protein of $2.8 \mathrm{~g} / \mathrm{dl}$. Cytological examination allowed a stronger suspicion of a hemangiosarcoma. The mare was euthanized in agreement with the owners due to the poor prognosis. The necropsy findings included thoracic effusion with a total of $85 \mathrm{I}$, a precardial red

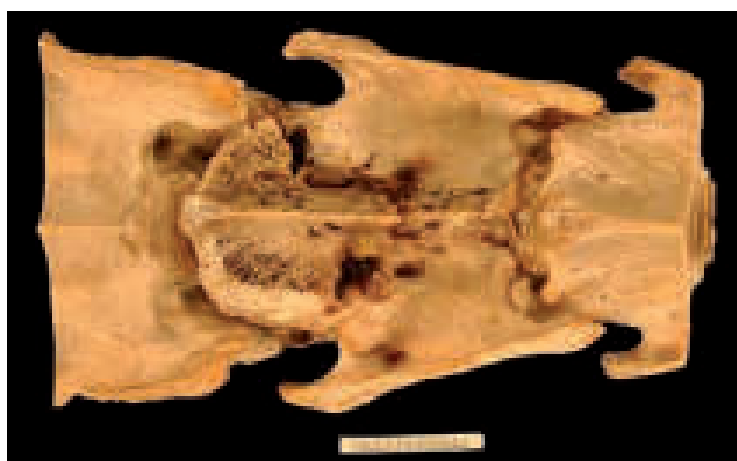

Fig.3 Macerated third cervical vertebrae, horse 1. Ventral view of the fractured C3 with a dislocated bone fragment

Mazerierter C3: Blick von ventral auf den frakturierten C3 mit disloziertem Fragment

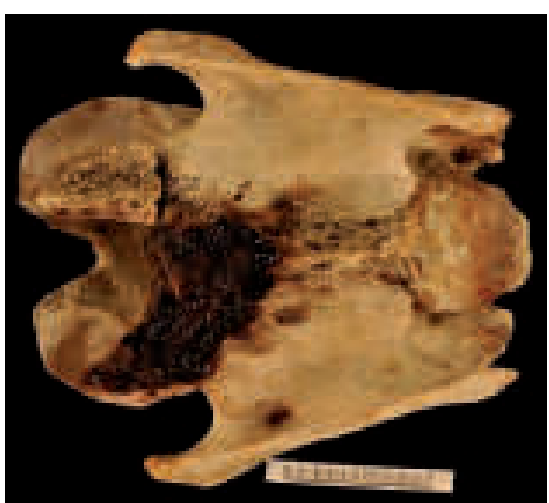

Fig.4 Macerated third cervical vertebrae, horse 1. Removal of the dislocated C3 bone fragment reveals a red and black hemangiosarcoma.

Mazerierter C3: Aufsicht auf das rot-schwarze Hämangiosarkom nach Entfernung des Fragmentes 
and black mass of $20 \times 8 \times 5 \mathrm{~cm}$, as well as multifocal black nodes of $1 \mathrm{~cm}$ diameter on the pleura. The mass was diagnosed histologically as a hemangiosarcoma of the pleura and mediastinum with metastases in the lung.

\section{Case 4}

A 21 -year-old Norwegian mare was presented at the Equine Clinic with a history of weight loss. Clinical examination revealed no abnormalities. Heart rate and respiratory rate were within the reference range. The mare showed severe edema of the pectoral region and of the ventral midline. A soft tissue swelling of approximately $20 \mathrm{~cm}$ length and $10 \mathrm{~cm}$ wide was evident on the right lateral chest wall, which was of hard consistence but indolent. The only laboratory abnormality was mild anemia (PCV 23\%). Thoracic effusion was diagnosed by radiography. Cytological examination of the thoracic aspirate suggested hemangiosarcoma. A symptomatic treatment for 14 days revealed no improvement. The mare was euthanized in agreement with the owners. At necropsy, a tumor of $15 \times 15 \times 7 \mathrm{~cm}$ size was found at the musculature of the right chest wall. An amount of 20 l of a serosanguinous transudate was collected in the thorax, where some red and black masses were found. Metastases in the lung, spleen and brain could be observed. A hemangiosarcoma was diagnosed.

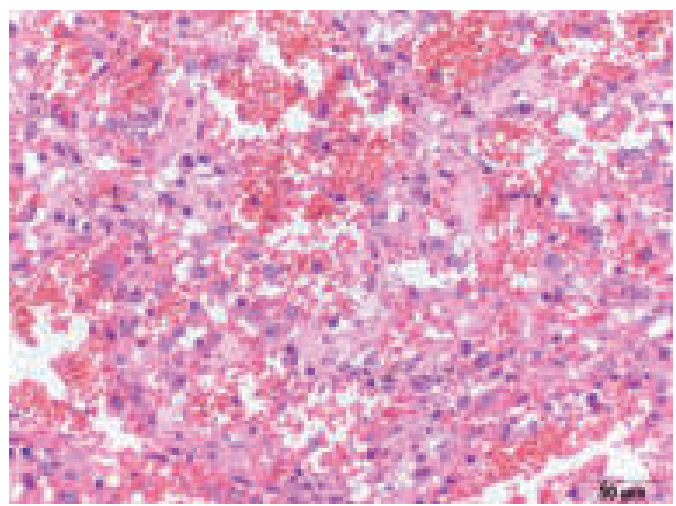

Fig.5 Cervical hemangiosarcoma; histologically, the tumor was composed of plump tumor cells surrounding blood filled caverns, HE stain 1000x magnification.

Histologisches Präparat des cervicalen Hämangiosarkoms, Tumorzellen umgeben Blutgefäße, HE-Färbung, 1000-fache Vergrößerung

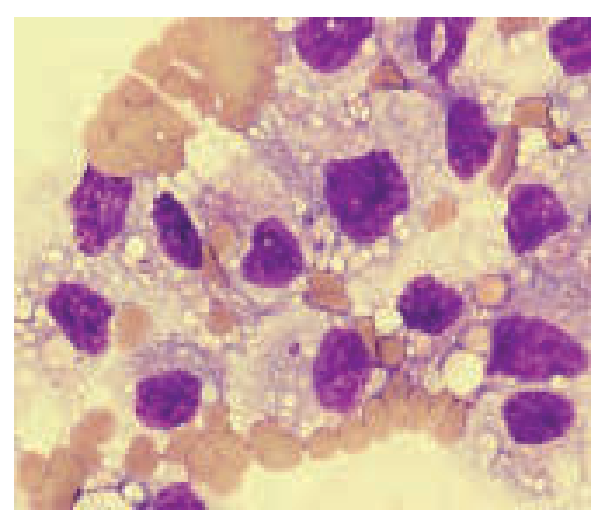

Fig.6 Cells with oval nucleus, basophilic and vacuolated cytoplasm, and harsh chromatin patterns in abdominal effusion of a horse with hemangiosarcoma (case 2), Diff-Quick-stain 1000x magnification Zellen mit ovalem Zellkern, basophilem und vakuolisierten Zytoplasma und scharf begrenzten Chromatinbestandteilen in dem Bauchhöhlenpunktat von Fall 2, Diff-Quick-Färbung, 1000-fache Vergrößerung

\section{Discussion}

Kennedy and Brown (Kennedy and Brown 1993) describe only 16 out of 27,604 equine neoplasms to be of vascular origin. Hemangiosarcomas are found in blood vessels of the skeletal musculature (Valentine et al. 1986a), but it is often difficult to localize the origin of the tumor because of rapid spreading throughout the different organs. A gender predilection is not reported (Southwood et al. 2000). The mean age of horses in this case report was 22.5 years. A review of the literature revealed a higher prevalence of hemangiosarcomas in older horses (Southwood et al. 2000), although younger horses can be affected (Johns et al. 2005). A typical localization of hemangiosarcoma is the skeletal musculature (as in case 4), but these neoplasms also occur in the thoracic (as in case 3) and in the abdominal cavity (as in case 2). Pleural or peritoneal effusions are common in these horses (Southwood et al. 2000) and our cases 2, 3 and 4 presented these symptoms as well. Cases 2, 3 and 4 also showed laboratory abnormalities, such as anemia and thrombocytopenia, which are described as indicative for neoplasms (Southwood et al. 2000, Valentine et al. 1986a). Hemangiosarcoma was suspected in three patients because of cytologic findings of the effusions of thorax or abdomen. Typical neoplastic cells are large and spindloid with large oval nuclei and prominent nucleoli of variable size and shape (DeHeer et al. 2002), but they often have a strong similarity to mesothelial cells in the Romanowsky stains (Schmitz and Grabner 2008). The nucleus is often localized in the center of the cell; the cytoplasm is basophilic and vacuolated. Nucleoli often show harsh chromatin patterns. Cells found individually or in clusters show anisokaryosis and anisocytosis as the criteria of malignancy. Abnormal mitotic figures are occasionally seen (Schmitz and Grabner 2008).

Reports of primary vertebral hemangiosarcoma in horses are rare. Some cases concerning hemangiosarcomas within in the vertebral canal in horses (Berry 1999, Kennedy and Brown 1993, Newton-Clarke et al. 1994) and in one miniature donkey (MacGillivary et al. 2003) have been published. All horses showed neurological deficits, such as ataxia and restricted movement of the neck. Case 1 of the series presented was unremarkable neurologically. Pain while moving the neck was the only peculiarity the gelding showed. He had neither remarkable clinical signs, such as ventral edema, tachycardia or weight loss, nor laboratory alterations. Pathological fractures of the vertebral bones caused by primary hemangiosarcoma have been described in men (Yamshita et al. 2012). Primary hemangiosarcomas are also known to cause pathological vertebral fractures in dogs (Mackenzie and Bellah 2003, Parchman and Crameri, 1989). To the best of the authors' knowledge, there have not been any reports about pathological vertebral fractures due to primary hemangiosarcoma in horses. Traumata, such as falling or accidents, are well-known to cause cervical vertebral fractures in horses. Osteomyelitis of the vertebral bones after systemic infection or stress fractures after high performance can cause pathological fractures of vertebral bones in horses (Wessum 2011 ). Severe pain, swelling of the affected area and painful movement of the neck, such as in case 1 , are common clinical symptoms of vertebral fractures (Dyson 2011 , Wessum 2011 ). Neurological deficits are anticipated when the vertebral canal is obstructed by tissue swel- 
ling, bleeding or bone fragments. No compression of the spinal cord was present in our case. The vertebral body affected showed a lytic opacity at the radiologic examination. This finding is described in cases of infiltration of the vertebral bones by some other neoplasms, such as lymphosacoma and extramedullary plasmacytomas (Butler et al. 2009). A conservative therapeutic approach to vertebral fractures includes anti-inflammatory and analgesic treatment combined with stable rest and controlled exercise (Wessum 2011 ). Surgical treatment options have also been described (Robertson and Samii 2012). Because of the advanced age of the gelding, the dislocation of the fragment and the guarded prognosis, the patient was euthanized. Even though hemangiosarcomas are rare in horses, they are to be considered as a differential diagnosis in cases with unspecific signs, such as chronic weight loss, ventral edema or tachycardia, especially in older horses. Laboratory alterations, swelling of skeletal musculature or fluid accumulations in the abdominal or thoracic cavity may be indicative for this neoplasia. The cytology of aspirates may allow an intra-vitam diagnosis of hemangiosarcomas, although the cells of have a strong similarity to mesothelial cells in the Romanowsky stains. Immunohistochemistry or immunocytological analyses are critical for the final diagnosis. Cases particularly like the first one can be an increased challenge for clinicians and exacerbate an intra-vitam diagnosis.

This case series is the first report about a pathological fracture of a cervical vertebra caused by a hemangiosarcoma in a horse.

\section{References}

Berry S.-I. (1999) Spinal cord compression secondary to hemangiosarcoma in a saddlebred stallion. Can. Vet. J. 40, 886-887

Butler J. A., Colles C. M., Dyson S. J., Kold S. E., Poulos P. W. (2009) The Spine. In Butler J. A., Colles C. M., Dyson S. J., Kold S. E., Poulos P. W. (eds.) Clinical Radiology of the Horse. 3 ed. Blackwell Publishing

Cissel D. D., Wisner E. R., Textor J., Mohr F. C., Scrivani P. V., Théon A. P. (2012) Computed tomographic appearance of equine sinonasal neoplasia. Vet. Radiol. Ultrasound 53, 245-251

DeHeer H. L., Parry B. W., Grindem C. B. (2002) Peritoneal Fluid. In Schrefer, J. A. (ed.) Diagnostic Cytology and Hematology of the Horse. 2 ed. St. Louis, Missouri: Rick L. Cowell, Ronald D. Tyler

Dunkel B. M., Piero F. D., Kraus B. M., Palmer J. E., Lin P. ,Wilkins P. A. (2004) Congenital Cutaneous, Oral, and Periarticular Hemangiosarcoma in a 9-Day-Old Rocky Mountain Horse. J. Vet. Intern. Med., 18, 252-255

Dyson S. J. (2011) Part V: The Axial Skeleton, The Cervical Spine and Soft Tissue of the Neck. In Ross, M. W., Dyson, S. J. (eds.) Diagnosis and Management of Lameness in the Horse. 2 ed. St. Lovis, Missouri, Elsevier Saunders

Gearhart P. M., Steficek B. A., Petersen-Jones S. M. (2007) Hemangiosarcoma and squamous cell carcinoma in the third eyelid of a horse. Vet. Ophthal. 10, 121-126

Johns I., Stephen J. O., Piero F. D., Richardson D. W., Wilkins P. A. (2005) Hemangiosarcoma in 11 Young Horses. J. Vet. Intern. Med. 19, 564-570

Kennedy F. A., Brown C. M. (1993) Vertebral angiosarcoma in a horse. J. Vet. Invest. 5, 125-127

Kiupel M., Frank N., Stevenson G. W., Siems J., Snyder P. W. (2000) Intrapelvic hemangiosarcoma in a horse. J. Vet. Diagn. Invest. 19, 91-95

Klopfleisch R., Klose P., Gruber A. D. (2010) The combined expression pattern of BMP2, LTBP4, and DERL1 discriminates malignant from benign canine mammary tumors. Vete. Pathol. 47, 446-454
Louise L. Southwood Schott H. C., Henry C. J., Kennedy F. A., Hines M. T., Geor R. J. , Hassel D. M. (2000) Disseminated Hemangiosarcoma in the Horse: 35 Cases. J. Vet. Intern. Med. 14, 105-109

MacGillivary K. C., Sweeney C. R., McLear R., Habecker P. L. (2003) Vertebral Body Hemangiosarcoma in a 16 -year-old miniature sicilian Donkey. Vet. Radiol. Ultrasound 44, 429-432

Mackenzie G. B., Bellah J. (2003) What Is You Diagnosis. J. Am. Vet. Med. Assoc., 222, 1075-1076

Newton-Clarke M. J., Guffoy M. R. G., Dykes N. L., Divers T. J. (1994) Ataxia due to a vertebral hemangiosarcoma in a horse. Vet. Rec., 135, 182

Parchman M. B., Crameri F. M. (1989) Primary vertebral hemangiosarcoma in a dog. J. Am. Vet. Med. Assoc. 194, 79-81

Recknage/ S., Nicke M., Schusser G. F. (2012) Diagnostische Aussagekraft der Zytologie von Bauchpunktaten bei abdominalen Tumoren des Pferdes. Tierärztl. Praxis G 40, 85-93

Reischaver A., Grosche A., Gieseler T., Jäger K., Huth H., Schoon H. A. (2006) Chronische Blutungsanämien bei zwei Pferden mit Hämangiosarkom. Pferdeheilkunde 22, 131-139

Robertson J. T., Samii V. F. (2012) Traumatic Disorders of the Spinal Column. In Aver, J. A. , Stick, J. A. (eds.) Equine Surgery. 4 ed. St. Louis, Missouri, Elsevier, Saunders

Schmitz R. R., Grabner A. (2008) Differenzialdiagnose innerer Tumore beim Pferd mit besonderer Berücksichtigung der Zytologie von Körperhöhlenpunktaten. Pferdeheilkunde 24, 353-366

Tyler R. D., Meinkoth J. H., Cowell R. L., McAllister C. G., Caruso K. J. (2002) Cutaneous and Subcutaneous Lesions, Masses, Cysts, and Fistulous Tracts. In Schrefer, J. A. (ed.) Diagnostic Cytology and Hematology of the Horse. 2 ed. St. Louis, Missouri Ronald D. Tylor, Rick L. Cowell

Valentine B., Ross C., Bump J., Eng V. (1986) Intramuscular hemangiosarcoma with pulmonary metastasis in a horse. J. Am. Vet. Med. Assoc. 188, 628-629

Wessum R. v. (2011) Lameness Associated with the Axial Skeleton. In Baxter, G. M. (ed.) Adams and Stashak's Lameness in Horses. 6 ed. Ames, lowa, USA, Wiley-Blachwell

Yamshita H., Endo K., Teshima R. (2012) Angiosarcoma of the proximal humerus: a case report and review of literature. Medical Case Rep. 6, 347-352

Deutsche Übersetzung

\section{Unterschiedliche klinische Ausprägungen des Hämangiosarkoms beim Pferd}

Tumore vaskulären Ursprungs treten beim Pferd selten auf. Hämangiosarkome sind maligne Tumoren, die ihren Ursprung vom vaskulären Endothel nehmen und in engem Kontakt zum Gefäßsystem stehen (Tyler et al. 2002). Sie können beim Pferd am Auge (Gearhart et al. 2007), in der Haut und Unterhaut, in Lunge und Pleura, Skelettmuskulatur und Milz (Southwood et al. 2000) auftreten. Eine lokale Invasion der Knochen (Johns et al. 2005), der Nasennebenhöhlen (Cissel et al. 2012), der Maulhöhle (Dunkel et al. 2004) sind ebenso beschrieben wie ein disseminiertes Auftreten in mehreren verschiedenen Organen. Hämangiosarkome können ihren primären Ursprung auch in Knochen nehmen. Wirbelkörper und platte Knochen des Schädels oder das Becken sind dabei bevorzugte Lokalisationen (Kiupel et al. 2000). Hämangiosarkome zeigen ein schnelles, infiltratives Wachstum und metastasieren in Lunge, Milz, Niere, Leber 
und Gehirn. Häufige klinische Symptome sind Tachykardie, Tachypnoe, Unterbauch-, Unterbrust- und Gliedmassenödeme (Southwood et al. 2000). Flüssigkeitsansammlungen in die Körperhöhlen, meistens im Sinne eines blutigen Transsudats, sind häufig zu beobachten. Durch eine zytologische Untersuchung dieser Punktate kann eine Tumordiagnose intra vitam ermöglicht werden (Recknage/ et al. 2012, Schmitz and Grabner 2008). Anämie, neutrophile Leukozytose und Thrombozytopenie sind häufige pathologische Befunde bei Laboruntersuchungen dieser Patienten (Southwood et al. 2000) und können den Tumorverdacht erhärten. Hinweisend sind auch eine Erhöhung der Enzymaktivitäten der LDH, AST und CK.

\section{Fallbeschreibungen}

Ein 21 -iähriger Kaltblutwallach wurde aufgrund einer Koliksymptomatik in der Klinik für Pferde der Freien Universität Berlin vorgestellt. Er fiel seit einigen Stunden mit vermehrtem Liegen, Zähneknirschen und einer reduzierten Futteraufnahme auf. Bei der Einlieferung in die Klinik zeigte der Wallach einen ungestörten Allgemeinzustand. Die klinische Allgemeinuntersuchung war ohne Auffälligkeiten. Die Untersuchung des Verdauungssystems, inklusive rektaler Untersuchung und dem Sondieren des Magens waren ohne besonderen Befund. Im Ultraschall der Bauchhöhle konnten keine pathologischen Befunde erhoben werden. Das entnommene Bauchpunktat war unauffällig. Die Blutparameter lagen im Referenzbereich. Der Wallach zeigte spontan eine anfallsartige Schmerzreaktion bei der Bewegung im Schritt. Bei der anschließend durchgeführten neurologischen Untersuchung konnte eine eingeschränkte Beweglichkeit des Halses festgestellt werden. Der Wallach zeigte sonst keine neurologischen Auffälligkeiten. Die Halswirbelsäule wurde mittels digitalem Röntgensystem (AGFA DX-G; AGFA Healthcare, Greenville, SC) untersucht. Es wurden latero-laterale und Schrägaufnahmen der Halswirbelsäule angefertigt. Die Röntgenkassette wurde dabei parallel beziehungsweise schräg am Pferdehals positioniert und ein Film-Focus-Abstand von $100 \mathrm{~cm}$ eingehalten. Auf den angefertigten Röntgenaufnahmen konnte eine Fraktur des caudoventralen Anteils des Wirbelkörpers des 3 . Halswirbels mit Dislokation des Fragmentes nach ventral diagnostiziert werden. Weiterhin war eine fleckige Aufhellung im Bereich des ventralen Wirbelkörpers auffällig (Abb. 1 und 2). Ein Trauma als Ursache konnte nicht sicher ausgeschlossen werden. Aufgrund des Alters des Pferdes und der vorsichtigen Prognose wurde der Wallach in Absprache mit den Besitzern euthanasiert und zur pathologisch-anatomischen Befunderhebung verbracht. In der Sektion konnte eine pathologische Fraktur des caudoventralen Wirbelkörpers des C3 aufgrund eines Hämangiosarkoms (Abb. 3, 4 und 5) diagnostiziert werden. In der ventralen Halswirbelsäulenmuskulatur konnte das Hämangiosarkom mit Muskelfaserdegeneration ebenfalls nachgewiesen werden. Die anderen Organe zeigten keine pathologischen Veränderungen.

Der zweite Fall hier vorgestellte Fall ist eine 28-jährige Traberstute, die aufgrund von Abmagerung und Durchfall in der Klinik für Pferde vorgestellt wurde. Sie zeigte vorberichtlich seit 4 Wochen rezidivierendes, einseitiges Nasenbluten und seit zwei Wochen eine Anämie. Zur weiteren Untersuchung wurde sie vom Haustierarzł in die Klinik überwiesen. Bei der klini- schen Untersuchung zeigte sich die Stute mit einem gestörten Allgemeinzustand. Sie hatte eine Tachykardie $160 / \mathrm{min}$, Referenzbereich: $28-40 / \mathrm{min})$, Tachypnoe (20/min, Referenzbereich: $8-16 / \mathrm{min}$ ) und eine erhöhte Körpertemperatur von $38,6^{\circ} \mathrm{C}$ (Referenzbereich: $37-38^{\circ} \mathrm{C}$ ). In der Blutuntersuchung stellte sich eine neutrophile Leukozytose $\left(15,3 \times 10^{9} /\right.$, Referenzbereich: $\left.5-10 \times 10^{9} / \mathrm{l}\right)$, eine Anämie (HKT 16\%, Referenzbereich 25-35\%) und eine Thrombozytopenie $\left(16 \times 10^{9} /\right.$ I, normal 90-250 $\left.\times 10^{9} / I\right)$ dar. Die Laktatdehydrogenase (LDH) war erhöht (1007 U/I, normal <250 U/I), ebenso der Plasmakalziumspiegel $(3,08 \mathrm{mmol} / \mathrm{l}$, normal $1,5-1,8 \mathrm{mmol} / \mathrm{l})$. Bei der endoskopischen Untersuchung der oberen Atemwege konnte eine geringgradige Blutspur aus dem Aditus maxillaris der linken Seite festgestellt werden. Bei der rektalen Untersuchung konnten knotige Veränderungen in der Milz palpiert werden. In der sonographischen Untersuchung wurden in beiden Nieren und in der Milz multiple, hyperechogene Areale dargestellt. Weiterhin konnte im Ultraschall vermehrt freie Bauchhöhlenflüssigkeit diagnostiziert werden. Diese wurde punktiert und anschließend zytologisch untersucht. Aufgrund der Veränderungen der Zytologie wurde der Verdacht auf ein Hämangiosarkom (Abb. 6) geäußert und die Stute auf Wunsch der Besitzer euthanasiert. Bei der pathologischen-anatomischen Befunderhebung konnte eine $30 \mathrm{~cm}$ im Durchmesser große Umfangsvermehrung im Bereich der Gekrösewurzel mit Einbeziehung der linken Niere, der linken Nebenniere, der Milz und der Serosa am Übergang zwischen Colon ascendens und Colon descendens diagnostiziert werden. Die Leber, beide Nieren, beide Nebennieren und die Lunge zeigten multiple bis zu $0,5 \mathrm{~cm}$ im Durchmesser große, abgekapselte Umfangsvermehrungen. Hauptbefund war ein hochgradig metastasierendes Hämangiosarkom, das die genannten Organe infiltrierte.

Der dritte Patient, eine 20-jährige Warmblutstute, wurde aufgrund einer seit zwei Tagen bestehenden Tachypnoe und Tachycardie in der Klinik für Pferde vorgestellt. Bei der klinischen Untersuchung stellte sich die Stute mit einem hochgradig gestörten Allgemeinbefinden, Tachykardie $(60 / \mathrm{min})$ und Tachypnoe $(28 / \mathrm{min})$ dar. Das Blutbild zeigte eine Hypoproteinämie $(4,4 \mathrm{~g} / \mathrm{dl}$, normal $6-8 \mathrm{~g} / \mathrm{dl})$ bei einem Hämatokrit von $31 \%$, eine Thrombozytopenie $\left(26 \times 10^{9} / \mathrm{l}\right.$, normal $\left.90-250 \times 10^{9} / \mathrm{l}\right)$ und eine Hyperglykämie von $7,8 \mathrm{mmol} / \mathrm{l}$ (normal 2,8-5 mmol/l). Bei der arteriellen Blutgasanalyse fiel ein deutlich reduzierter Saverstoffpartialdruck von $58,5 \mathrm{mmHg}$ (normal $95-105 \mathrm{mmHg}$ ) auf. Die Auskultation der Lunge erschien gedämpft. In der Röntgenaufnahme des Thorax konnte ein hochgradiger Thoraxerguss diagnostiziert werden. In der ultrasonographischen Untersuchung des Thorax stellte sich hypoechogene Flüssigkeit im gesamten Thorax dar. Der Thoraxerguss wurde unter sterilen Kautelen punktiert und zytologisch untersucht, wobei sich der Verdacht eines Hämangiosarkoms ergab. Das gewonnene modifizierte Transsudat enthielt 2,2 $\times 10^{9} /$ I Leukozyten, ein HKT von 6,8\% und ein Gesamteiweiß von 2,8g/dl. Die Milz zeigte multiple hyperechogene Areale im Ultraschall. Aufgrund der vorsichtigen Prognose wurde die Stute auf Wunsch der Besitzer euthanasiert. Bei der pathologisch-anatomischen Untersuchung konnten $85 \mathrm{I}$ eines serosanguinösen Thoraxergusses gewonnen werden. Weiterhin konnte eine $20 \times 8 \times 5 \mathrm{~cm}$ große rotschwarze Masse präcardial festgestellt werden. Auf der Pleura ließen sich multifokale, harte, schwarze, erhabene Auflagerungen von $1 \mathrm{~cm}$ Durchmesser feststellen. Es wurde die Dia- 
gnose eines infiltrativ wachsenden Hämangiosarkoms in Pleura und Mediastinum mit Metastasierung in das Lungenparenchym gestellt.

Der vierte vorgestellte Fall ist eine 21 -jährige Norwegerstute. Sie wurde in der Klinik für Pferde aufgrund eines deutlichen Gewichtsverlustes vorgestellt. Bei der Allgemeinuntersuchung zeigte die Stute ein ungestörtes Allgemeinbefinden. Herz- und Atemfrequenz lagen im Referenzbereich. Die Stute zeigte ein mittelgradiges Unterbrust- und Unterbauchödem und eine honigmelonengroße Umfangsvermehrung an der seitlichen Thoraxwand, caudal des Ellbogens. Diese Umfangsvermehrung war von fester Konsistenz. Die Buglymphknoten waren beidseitig faustgroß geschwollen. Im Blutbild konnte eine Anämie (HKT 23\%) nachgewiesen werden. Die anderen Laborparameter lagen im Referenzbereich. Durch eine röntgenologische Untersuchung des Thorax wurde ein Thoraxerguss diagnostiziert. Dieser wurde punktiert und stellte sich als blutig-seröses, modifiziertes Transsudat dar. Die zytologische Untersuchung des Punktats ergab die Verdachtsdiagnose auf ein Hämangiosarkom. Es wurde eine Glukokortikoidtherapie (Dexamethason) in ausschleichender Dosierung (initial $0,1 \mathrm{mg} / \mathrm{kg}$ i.v.) begonnen. Der Zustand der Stute verschlechterte sich in den nächsten Tagen, sodass sie in Absprache mit den Besitzern schließlich euthanasiert und zur pathologischanatomischen Untersuchung überstellt wurde. In der Sektion wurden in der Brusthöhle 201 eines serosanguinösen Ergusses gewonnen. Am Brusteingang waren mehrere konfluierende $15 \times 15 \times 10 \mathrm{~cm}$ große, derbe Umfangsvermehrungen mit roter Schnittfläche zu finden. An der rechten Thoraxwand befand sich eine $15 \times 10 \times 7 \mathrm{~cm}$ große Umfangsvermehrung. In der Lunge, Milz und im Gehirn waren mehrere rote $0,5 \mathrm{~cm}$ große Umfangsvermehrungen sichtbar. Es wurde die Diagnose eines Hämangiosarkoms gestellt.

\section{Diskussion}

Von 27.604 Patienten wurde nur bei 16 Pferden durch Kennedy und Brown (1993) ein Tumor vaskulären Ursprungs diagnostiziert. Hämangiosarkome sind in den Blutgefäßen der Muskulatur zu finden (Valentine et al. 1986), doch oft ist es durch die hohe Metastasierungsrate schwierig, den Tumorursprung auszumachen. Die beschriebenen Fälle 2-4 waren jeweils Stuten, obwohl eine Geschlechtsprädisposition bei Hämangiosarkomen nicht bekannt ist (Southwood et al. 2000). Vorwiegend ältere Pferde sind betroffen (Southwood et al. 2000), dieser Tumor ist aber auch bei jungen Pferden zu finden (Johns et al. 2005). Eine typische Lokalisation ist die Muskulatur (Fall 4). Die Tumoren treten auch in der Brusthöhle (Fall 3) oder in der Bauchhöhle (Fall 2) auf. Häufig sind Flüssigkeitsansammlungen in Körperhöhlen (Fälle 2-4) (Southwood et al. 2000). Die Fälle 2-4 zeigten Laborveränderungen wie Anämie und Thrombozytopenie, die für Tumoren hinweisend sein können (Southwood et al. 2000, Unterschiedliche klinische Ausprägungen des Hämangiosarkoms beim Pferd. (Valentine et al. 1986, Reischaver et al. 2006). Die Verdachtsdiagnose Hämangiosarkom konnte bei den drei Fällen mit Ergüssen über die Zytologie der Punktate gestellt werden. Neoplastische Zellen sind groß, spindelförmig, besitzen einen großen ovalen Zellkern mit prominenten
Nukleoli unterschiedlicher Größe und Form (DeHeer et al. 2002), haben aber in der Romanoswsky-Färbung große Ähnlichkeit mit Mesothelzellen (Schmitz und Grabner 2008). Der Zellkern befindet sich zentral, das Zytoplasma ist basophil und vakuolisiert. Die Nukleoli zeigen scharf begrenzte Chromatinbestandteile. Die Zellen zeigen Anisokaryose, Anisozytose und abnorme Mitosefiguren als Malignitätskriterien (Schmitz und Grabner 2008). Berichte über primäre Angiosarkome in der Halswirbelsäule beim Pferd sind rar. Es existieren einzelne Falldokumentation über Hämangiosarkome innerhalb des Wirbelkanals bei Pferden (Berry 1999, Kennedy und Brown 1993, Newton-Clarke et al., 1994) und einem Miniaturesel (MacGillivary et al. 2003). Alle Pferde zeigten neurologische Defizite, wie eine Ataxie und eingeschränkte Halsbeweglichkeit. Im Gegensatz dazu war der beschriebene Fall 1 bei der neurologischen Untersuchung unauffällig. Lediglich eine eingeschränkte und schmerzhafte Halsbeweglichkeit fielen bei dem Wallach auf. Auch fehlten bei diesem Pferd die häufig beschriebenen Symptome wie Ödeme, Tachykardie, Gewichtsverlust oder die geschilderten Laborveränderungen (Southwood et al. 2000, Reischaver et al. 2006, Valentine et al. 1986). In der Humanmedizin sind pathologische Frakturen durch Hämangiosarkome als primäre Knochentumoren beschrieben (Yamshita et al. 2012). Auch bei Hunden kommen primäre vertebrale Hämangiosarkome als Ursache für pathologische Wirbelfrakturen vor (Mackenzie and Bellah 2003, Parchman and Crameri 1989). Ursächlich für Frakturen der Halswirbel beim Pferd sind meist Traumata, wie Stürze. Pathologische Halswirbelfrakturen können durch Osteomyelitis nach systemischen Infektionen bedingt sein oder als Stressfrakturen auftreten (Wessum 2011). Symptome solcher Halswirbelfrakturen sind Schmerzen und Muskelschwellungen in der betroffenen Region und eine eingeschränkte Halsbeweglichkeit (Dyson 2011, Wessum 2011). Diese stimmen mit den beschriebenen Symptomen des Wallachs überein. Neurologische Auffälligkeiten sind nur dann zu erwarten, wenn der Wirbelkanal durch eine Weichteilschwellung, Einblutung oder Fragmente eingeengt wird. Bei diesem Pferd wurde der Wirbelkanal nicht eingeengt, sodass keine neurologischen Ausfälle auftraten. Röntgenologisch konnte eine fleckige Aufhellung des betroffenen Wirbelkörpers diagnostiziert werden. Das ist auch bei anderen Tumoren (Lymphosarkom, Plasmazellmyelom), die die Halswirbel infiltrieren, beschrieben (Butler et al. 2009). Eine mögliche Therapie bei Halswirbelfrakturen wäre die antiphlogistische/analgetische Therapie und Boxenruhe (Wessum 2011).

Bei Pferden, mit unspezifischen Symptomen wie chronischem Gewichtsverlust, Unterbauch-, und Unterbrustödem oder Tachkardie, sollte eine Tumorerkrankung in die Differentialdiagnostik eingeschlossen werden. Hinweisend fur Hämangiosarkome können Laborveränderungen, Umfangsvermehrungen in der Muskulatur oder Flüssigkeitsansammlungen in Körperhöhlen sein. Die zytologische Untersuchung dieser Flüssigkeiten kann eine Diagnose ermöglichen. Ein untypischer Verlauf, wie bei Fall 1, kann den Kliniker aber vor Herausforderungen stellen und die Diagnosefindung erschweren.

Schlüsselwörter: Pferd / Hämangiosarkom / Halswirbel / Fraktur / Neoplasie / Onkologie 